\title{
RETURN MIGRATION IN BRAZIL
}

\author{
BAPTISTA, Emerson Augusto; ${ }^{*}$ CAMPOS, Jarvis; ${ }^{\text {b }}$ RIGOTTI, José Irineu Rangel c
}

\begin{abstract}
(a) Brown University. PhD in Demography, Federal University of Minas Gerais (UFMG). http://lattes.cnpq.br/2603731850009701
(b) $\mathrm{PhD}$ student in Demography, Federal University of Minas Gerais (UFMG). http://lattes.cnpq.br/9521949677900552

(c) Professor and PhD in Demography, Federal University of Minas Gerais (UFMG). http://lattes.cnpq.br/8454271156470204
\end{abstract}

\section{(*) CORRESPONDING AUTHOR}

Address: UFMG, Departamento de Demografia - Cedeplar. Avenida Presidente Antônio Carlos, 6627, Pampulha, CEP: 31270-901. Belo Horizonte (MG), Brazil. Tel: (+55 31) 3409-7203.

E-mail: emersonaug@yahoo.com.br

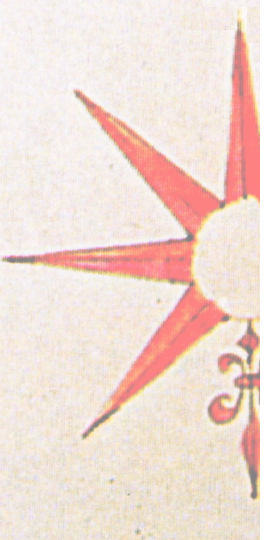

\begin{abstract}
The various forms of migration and mobility are factors that have historically played an important role in the socioeconomic development of a country. Among the different types of migration is the focus of this study: return migration, one of the main events in Brazilian population dynamics in recent decades. Thus, the main purpose of this article is to discuss some relevant theoretical elements for studies on return migration and second, to analyze the direct effect of this type of migration by federated units (FUs) in Brazil over the five-year periods 1986/1991, 1995/2000 and 2005/2010. In this way, it is possible to assess the return of natives to FUs, as well as short-term migration (full return migration). To this end, data was taken from the sample of the Demographic Censuses in 1991, 2000 and 2010 and the digital mesh of Brazilian FUs.
\end{abstract}

Keywords: Migration; Return migration; Spatial distribution; Brazil.

\section{RESUMO/ RESUMEN}

\section{MIGRAÇÃO DE RETORNO NO BRASIL}

As diversas formas de migração e mobilidade são fatores que, historicamente, tem desempenhado importante papel no desenvolvimento socioeconômico de um país. Dentre os diversos tipos de migração, encontra-se aquele que será focado neste estudo: a migração de retorno, um dos principais eventos ocorridos na dinâmica populacional brasileira nas últimas décadas. Sendo assim, o objetivo principal deste artigo será discutir alguns elementos teóricos relevantes para os estudos sobre migração de retorno e, num segundo momento, analisar o efeito direto deste tipo de migracão por unidades da federação (UF's) do Brasil para os quinquênios de 1986/1991, 1995/2000 e 2005/2010. Desta forma, será possível avaliar o retorno de naturais às UF's, bem como das migrações de curto prazo (migração de retorno pleno). Para tanto, serão utilizados os dados da amostra dos Censos Demográficos de 1991, 2000 e 2010 e a malha digital das unidades federativas brasileiras.

Palavras-chave: Migração; Migração de retorno; Distribuição espacial; Brasil.

\section{MIGRACIÓN DE RETORNO EN BRASIL}

Las diversas formas de migración y la movilidad son factores que históricamente ha jugado un papel importante en el desarrollo socioeconómico de un país. Entre los diferentes tipos de migración, es uno que se centra en este estudio: la migración de retorno, uno de los principales acontecimientos en la dinámica poblacional de Brasil en las últimas décadas. Así, el objetivo principal de este artículo discutiremos algunos elementos teóricos relevantes para los estudios sobre la migración de retorno y, segundo, para analizar el efecto directo de tal migración para las unidades de la federación (UF) de Brasil a los períodos de cinco años 1986 / 1.991, 1995/2000 y 2005/2010. Esto hará que sea posible evaluar el retorno natural de UF, así como la migración a corto plazo (la migración de retorno completo). Para ello, se utilizaron los datos de la muestra del Censo Demográfico 1991, el 2000 y 2010 y la malla digital de los estados brasileños.

Palabras clave: Migración; Migración de retorno; Distribución espacial; Brasil. 


\section{INTRODUCTION}

Return migration has played an important role in the scenario of migration in Brazil, especially in recent decades. States like Minas Gerais and the nine that make up the Brazilian Northeast, which historically have been considered "labor providers", have shown trends of recovery from the negative net migration observed in previous decades. The specific literature on the subject confirms that the flow of return migrants in recent decades has been more intense and directed to these particular states (COSTA, 2007).

A return migrant is understood to be a person who has left their place of origin, lived for some time in another region and then returned to their birthplace. In general, individuals leave for economic reasons, that is, they go in search of better job opportunities in the expectation of increasing their income. Their return is often found to be due to an error in assessing the opportunities in the destination, which results in frustration when their expectations about the desired improvements are not met.

On the other hand, migration can be part also of a long-term plan to change residence, when the migrant is positioned as a worker who will aggregate goods and / or benefits during their stay elsewhere before returning, older, to their place of origin and so enjoy old age with their families (COSTA, 2007).

Sayad (2000 apud Fazito, 2005) states that the life cycle of migration closes with the return to the homeland, because the return is a symbolic principle that inscribes circularity on migration. Thus, empirical migration systems act as an essential step: the return is the symbolic base of each and every displacement and also has a structural function in the topology of these systems because it dynamizes the migration process.

This paper aims to discuss some relevant theoretical elements for studies on return migration and, second, to analyze the direct effect of this type of migration on Brazilian federated units over the five-year periods of 1986/1991, 1995/2000 and 2005 / 2010. Finally, the article concludes with some considerations.

\section{RETURN MIGRATION}

Migration is a complex demographic phenomenon, because at the same time that a migratory flow has universal characteristics and is structurally similar to other flows, it historically and socially develops its uniqueness (DAVIS1989 apud FAZITO, 2005).

Within the broader framework that addresses migration there is return migration.

$[\ldots]$ The condition of returning is always latent in the essence of the emigrant / immigrant. The return is, of course, the desire and the dream of all immigrants, it is like recovering one's vision, the light missing for the blind, but like blind men, they know that this is an impossible operation. All that remains is to take refuge in an uneasy nostalgia or homesickness (SAYAD, 2000).

In the view of Sayad (2000), the sentiment of the return is intrinsic to the migrant, who leaves already thinking of their return, which confirms Martins' statement (1986) that migrants do not feel at home when they migrate and no matter how long their migration, and as much as the return does not occur, the sentiment of return, the nostalgia for their birthplace will always be part of them.

In fact, nostalgia is not the evil of the return, because once it happens it turns out that it is not the solution: there is no real return (to the identical). On the one hand, one can always go back to the point of origin, space lends itself well to this coming and going, on the other hand, one cannot return to the time of the departure, to become the person one was at that time, or rediscover the same situation, places and people left behind, as they were then (SAYAD, 2000). 
The return is also a constitutive condition of the immigrant's condition, a paradox inherent in the constitution of the phenomenon of migration that defines and unifies, as the notion of return "is intrinsically circumscribed to the designation and idea of emigration and immigration. There is no immigration in one place without there having been emigration from somewhere else; there is no presence anywhere that does not have a counterpart of an absence elsewhere" (FAZITO, 2005).

The migrant is one who, when moving spatially enters a contradictory space of subjective temporality. There is the desire to return and for real and effective permanence, in which there is a need to prolong the stay, leading to a specific sociocultural context. In this context, the spatial move itself implies a temporal change in which the "migration" event demarcates the present, past and future. The identity of the migrant is linked to this temporality, allowing a sense of familiarity linking these three times. The sense of temporariness acts as an "anchor" that allows migrants to survive (spatially) away from their history, their beliefs, values, and customs, in short, all that was known and familiar, but that is now far away. Thinking about the possibility, however remote, of their return allows them to ensure themselves as individuals in a "strange society" (COSTA, 2007).

Depending on local conditions, the immigrant can choose between two paths: either to return to their society (reinsertion), or remain definitively in the immigration location (insertion). Having contact with a different culture, different people, different habits and environments is always positive, when considering personal development. However, as observed in various situations identified by Fazito (2005), the skills acquired can often turn out to be real obstacles to the rehabilitation of returnees to the societies of origin and can act as conflict enhancers with non-migrants. "So neither the money saved nor the technical skills acquired seem to fulfill a definitive role in the rehabilitation of the returnees in their communities of origin" (FAZITO, 2005).

From the point of view of measurement techniques, with the focus on the research done in Brazil (RIBEIRO et al. 1998; RIBEIRO; CARVALHO, 1998; CARVALHO, 2004), we concluded that return migration has a major impact on the social process of migration, definitely contributing to the strengthening and expansion of migration flows (FAZITO, 2005). As the return is an intrinsic condition of the migrant a historical perspective is always essential to understand migratory flows, as it is to be expected that the places that were an origin in the past would then become a destination for older emigrants.

In general, the assumption is that the return is not simply due to economic "success" or "failure" in the destination's labor market, but it also relates to the actual life cycle of migrants, as well as the historical periods that have marked the various regions.

\section{RETURN MIGRATION IN BRAZIL}

According to Cunha and Baeninger (2001), the 1980s represented a time of important changes in Brazilian migratory history, particularly in relation to historical trends of spatial redistribution of the population. Thus, parallel to the drastic reduction of certain migratory flows to the Southeast or to frontier areas, it is possible to identify an intensification of return movements, processes that shape the new reality of the country's socioeconomic development, in particular regarding the possibilities of the insertion of migrants in the major urban centers.

Return migration is undoubtedly one of the main phenomena occurring in Brazilian migration in recent decades. The regions that traditionally supplied labor, such as Minas Gerais and the Northeast, have shown a trend of recovery of their emigrant population. In the first case, for example, it was found that from 1980 to 2000 there was an increase in the proportion of native mineiros (those born in Minas Gerais) residing in Minas Gerais and a reduction in the proportion of native mineiros residing in São Paulo, Rio de Janeiro, Parana and Goias. At the same time, there was a proportional increase of persons born in São Paulo, Rio de Janeiro, Parana and Goias among the residents of Minas Gerais. The two phenomena are related and represent, in part, what are called 
the direct and indirect effects ${ }^{1}$ of return migration of native mineiros to their place (FU) of birth (GARCIA and RIBEIRO, 2004). This information is corroborated and complemented by Cunha and Baeninger (2005):

[...] The volume of return migration has increased enormously in the country in the last 30 years; in the 1990 s there was a relative increase of $221 \%$ in relation to the volume of this migration in the 1970 s. This extremely high growth contributed to the rise in the number of people returning to their states of birth from 1.1 million in the 1970s to almost 3.8 million in the 1990s. These amounts indicate the importance this type of mobility (always present, but to a lesser degree) has acquired in the setting of national migration in recent years.

Fixed date census data, ${ }^{2}{ }^{3}$ reveals that in Brazil about 1,335,000 individuals decided to return to their home states between the years 1995-2000 (IBGE, 2000). This is a significant number considering that among the people who were displaced in this period about $22 \%$ were returnees. Of these, the most intense flow of return migration is directed to the Northeast, about $40 \%$ of the total returnees.

This is a relatively new phenomenon, although according Baeninger (2000) the 1991 census, had already pointed to this trend in the behavior of Brazilian migration. Information is needed about these individuals who are returning and whether in fact, they represent gains to the receiving area. In 2003, the author ratified this trend:

In the dynamic Brazilian urban network, migratory movements have become a key element of population growth, ${ }^{4}$ even if the intensity of arrivals and exits of people does not always materialize in the resulting numbers as expressed by growth rates. The marked spatial mobility of the population can be seen in locations of different sizes, indicating that the current urbanization process in Brazil is still marked by significant population movements, especially from urban areas, regardless of size, to other urban areas (BAENINGER, 2003).

In the case of Brazil, there is an indication that the "remigration" of young people with secondary schooling is due to frustrated expectations regarding the employment, income and living conditions at the destination, which makes these individuals return to their places of birth, where local knowledge and a network of friends and family can facilitate their absorption into the local labor market. However, this scenario also includes the return of seniors, who were successful in their decision to migrate and are returning to spend their old age with their families (COSTA, 2007).

\section{THE PROFILE OF BRAZILIAN RETURN MIGRANTS}

Studies in Brazil show evidence of positive selectivity in the initial group of migrants (SANTOS JUNIOR et al., 2005, JUSTO and SILVEIRA NETO, 2006). These studies indicate that migrants are, on average, people with more education, younger, with higher levels of income and hours worked. However, these studies are not concerned with demonstrating the enhanced selectivity for the group of returnees.

\footnotetext{
1 In general, the direct effect of return migration on a particular FU refers to all natives who have returned to this unit of the federation (FU) in the decade prior to the date of the census used as a source of data. The indirect effect arises from the immigration of non-natives, coupled with the return of natives or stems from the birth of children of returnees (of the returnee women) in the destination FU (RIBEIRO, 1997). The basic information for this analysis records the previous place of residence of the returnee, known as the "last step" question.

2 It corresponds to migrants who, five years ago, did not live in the FU where they lived on the date of the census.

3 The 2000 IBGE census shows that about 5,259,000 individuals reported having lived in another unit of the federation in 1995.

4 With the decline in fertility and the continuous decline in mortality for many locations migration has accounted for a significant portion of the population increase.
} 
From the 1980 Census onward, it is possible to construct the profile of returning migrants. The data shows that these migrants are, on average, older than those who have not returned; a result that is equivalent to those obtained in other countries, where migration is made up of older people, although with less schooling.

This peculiarity of Brazilian return migration is a sign that for many of the returnees migration was successful, since during its course the returnee acquired more schooling, returning to the labor market in his homeland with more skills. In this case, they come back with better prospects and can thrive in their place of origin.

It is noteworthy that although the profile of Brazilian return migrants is linked to relatively more advanced ages, frustrations about the materialization of employment and income in the destination force some younger people to return to their birthplace, even when they are still fully productive and could be enjoying the gains from migration.

According to Cunha (2006), the non-returning Brazilian migrant from the beginning of this century is in fact young and about $70 \%$ are between 15 and 49 years old. The ratio between women and men is the same as that present in the total national population, according to the 2004 PNAD data. The migrant is slightly more educated than average, but, according to Cunha (2006) this is more a reflection of the migrant's age than a differential in relation to non-migrants. In addition to education, the migrant's profile also varies according to the region. States in the Northeast, as well as the Center-west, have heavy losses of well-educated people.

In Brazilian literature, the aspect of "remigration" and migration to backward regions has been stressed very little, except in works that explored the importance of the issue for the spatial redistribution of the population (GARCIA and RIBEIRO, 2004 and RIBEIRO, 1997).

Return migration becomes increasingly important in the context of interstate migration, given the new dynamics and emerging migration patterns. Ribeiro (1997), when analyzing the information about the Brazilian Northeast and referencing Martine (1994) records:

The phenomenon of the northeastern return can be analyzed on the one hand, from a sociological perspective, that is, it represents a return to places of origin, where the network of relationships and knowledge facilitates survival during crisis years. From an economic point of view and a more optimistic complementary interpretation, the return may be linked to the fact that during the 1980s, the Northeast showed positive signs, for example, a more efficient administration, the opening up of new sources of work, etc., these facts would have encouraged the return.

For Sayad (2000), the return does not always take place in a very satisfactory way, because returnees are looking for the time they left behind in the space they left behind. In other words, they expect that everything will be as it was before in their place of origin, a fact that does not occur, because time has also passed in that place. Not only are there physical changes but mainly changes to the people from their land.

Martine, quoted by Brito (2003), gives evidence regarding the hypotheses that during their trajectory migrants go through a set of steps in a kind of progressive socialization, until they reach a final destination, where they are fully absorbed by the economy and society. In addition to this possibility, once in their final destination and after a certain time of residence, migrants tend to increase their integration capacity at the destination, improving their level of education and occupation and hence their income, which fuels their return to their place of origin.

In an attempt to analyze the recent role of return migration, the text below comments on how population censuses can aid this task and then discusses the relevance and evolution of this type of mobility for the Brazilian case. 
METHODOLOGY

In this article, we will use direct migration techniques to calculate the number of immigrants and emigrants of the federated units and consequently the net migration balance.

Direct migration techniques correspond to "(...) estimation procedures that use the census questions relating to migrants" (RIGOTTI, 1999). Among the direct techniques, the variable for last place of residence is used, which corresponds to people who lived in another municipality from the site of the census. This aspect, combined with residence time allows the definition of the last migratory step. ${ }^{5}$ This information combines the spatial and temporal dimensions ${ }^{6}$ (RIGOTTI, 1999).

In turn, the fixed date of the survey allows the calculation (not estimates) of net migration and population flows, using the combination of the place of residence five years ago and the current place of residence, although nothing is known about the intermediate stages. Thus, the net migration balance can be defined as "the difference between the volume of those not living in the region at the beginning of the period under analysis and migrated there (immigrants), and those who were living there at the beginning of the period and left (emigrants) (RIGOTTI, 1999).

With the purpose of, first, to contextualize interstate migration in Brazil, and, second, to identify and contextualize the current situation and the main migration trends (an important task, given the recent availability of microdata from the 2010 Census), fixed date questions were used to calculate and map the migratory balance, net migration rates (NMRs) ${ }^{7}$ and five-year flows for the federated units in the five-year periods 1986/1991, 1995/2000 and 2005/2010. Regarding last stage migration, immigrants and emigrants were calculated, with a residence time less than 5 years and aged over 5 years. This criterion was adopted to construct short-term migration, which will be discussed later.

Regarding return migration, Carvalho and Rigotti (1998) state that it "should consider as a return of a period all immigrants in the period who, sometime in the past, had resided in the area under study." With the introduction of the fixed date question in the 1991 Census, new possibilities arose to measure return migration. According to Carvalho and Rigotti, one can calculate the return occurring within each of the five-year periods considered, regardless of the migrant being native or not to the geographical area. In this context, calculations were made regarding fixed date return migrants, the relative proportion of this group in relation to the total of fixed date immigrants and the five-year flows of this segment of the migrant population, in addition to short-term migrants, here understood as those who lived in the geographical unit at the beginning of the period, emigrated and then returned before the date of the census.

Figure 1, taken from Rigotti (1999), shows an explanatory example of the concept of short-term return migrants, which will be used herein.

According to Carvalho and Rigotti (1998), the term full return migrant indicates that the two steps necessary to characterize return migration have been accomplished, while the term return migrant fits to all those who, in the period under review, carried out at least the second step of the process (immigration).

In the example above, on the fixed date the individual declares municipality $A$ as the place of residence in 1986 and municipality $\mathrm{B}$ as the previous place of residence. It is also known that the individual lived only two years in municipality A (through the residence time variable), a situation which corresponds to full return migration within the five year period (since they resided in A in 1986 , left and returned within the period), whether the person is a native of the municipality or not.

\footnotetext{
5 This corresponds to migrants with less than five years of residence in the FU, aged five or older.

6 The data compiled in this article correspond to internal migration, i.e., international migration was excluded.

7 The NMR is "the proportion of the population observed in the second census resulting from the migratory process when the rate is positive, and the proportion by which the population would increase in the absence of migration, if negative" (CARVALHO; RIGOTTI, 1998).
} 


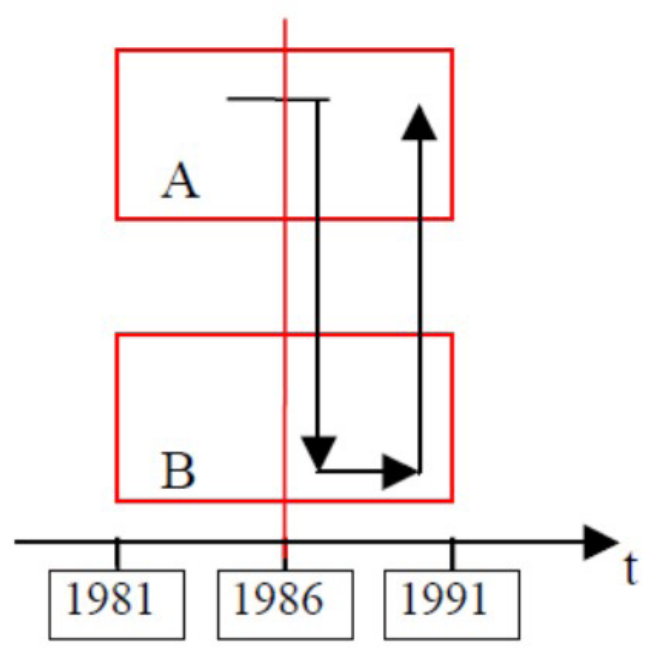

Figure 1- Simulation of short-term migration Source: Taken from Rigotti (1999)

Once the information on the migrants is compatible, taking into account only those in the last stage who resided for 5 years in the FU and were over 5 years of age, there will be more last stage immigrants compared with fixed date ones, as all fixed-date immigrants will also be in the last stage, but the returnees will not be included among the fixed date ones, but in the last stage group. ${ }^{8}$

Importantly, in this study the indirect effects were not taken into account. In this case, children born after the parents return and "immigrants who are not returning but immigrated as a result of the return migration of spouses, children, etc. (CARVALHO; RIGOTTI, 1998).

\section{RESULTS AND DISCUSSION}

The data in Table 1 shows that the total population has increased over the last three population census in all FUs, to a greater or lesser extent. Migratory balances oscillated in each State. In the Northern region, for example, Acre showed negative net migration balances and rates in the three five-year periods analyzed. It is noted that in addition to the balances being near zero for this state there was also low mobility, as in the whole period both immigrants and emigrants were around 15,000 people; unlike other states in the region, which also had lower migration balances but higher order population flows, as shown in Table 1. Besides Acre, in the Northern region only Pará had a population loss in the last two five-year periods (1995/2000 and 2005/2010), due to the significant loss of population to Amazonas, especially in the five-year period 1995/2000, as can be seen in Figure 2a. Moreover, the other states of this region showed positive net migration balances and rates in all the periods analyzed. The immigrants mainly originated from the State of Maranhão with the destination being principally the State of Pará (Figure 2a). Also in relation to net population gains, the State of Roraima is noteworthy for its high net migration rates for the first two five-year periods, $13.17 \%$ and $10.29 \%$, respectively.

In the Northeast region, with the exception of Rio Grande do Norte in the last two five-year periods, and Sergipe in the five-year periods 1986/1991 and 2005/2010, all other states had negative net balances and rates. Although a decrease has been observed in migratory losses from the Northeast over the past 25 years, with net migration rates of $-2.06 \%,-1.60 \%$ and $-1.32 \%$ respectively in the three five-year periods, this loss is considerable because there was a negative net migration of 701,078 people in the five-year period 2005-2010. Although migrants originating from the Northeast have the State of São Paulo as their main destination (a phenomenon observed in the three five-year periods under review), the maps in Figure 2 show that the intensity of these flows has been decreasing in recent decades. In the five-year periods 1986/1991 and 1995/2000, the states of

\footnotetext{
$8 \quad$ View (RIGOTTI, 1999).
} 


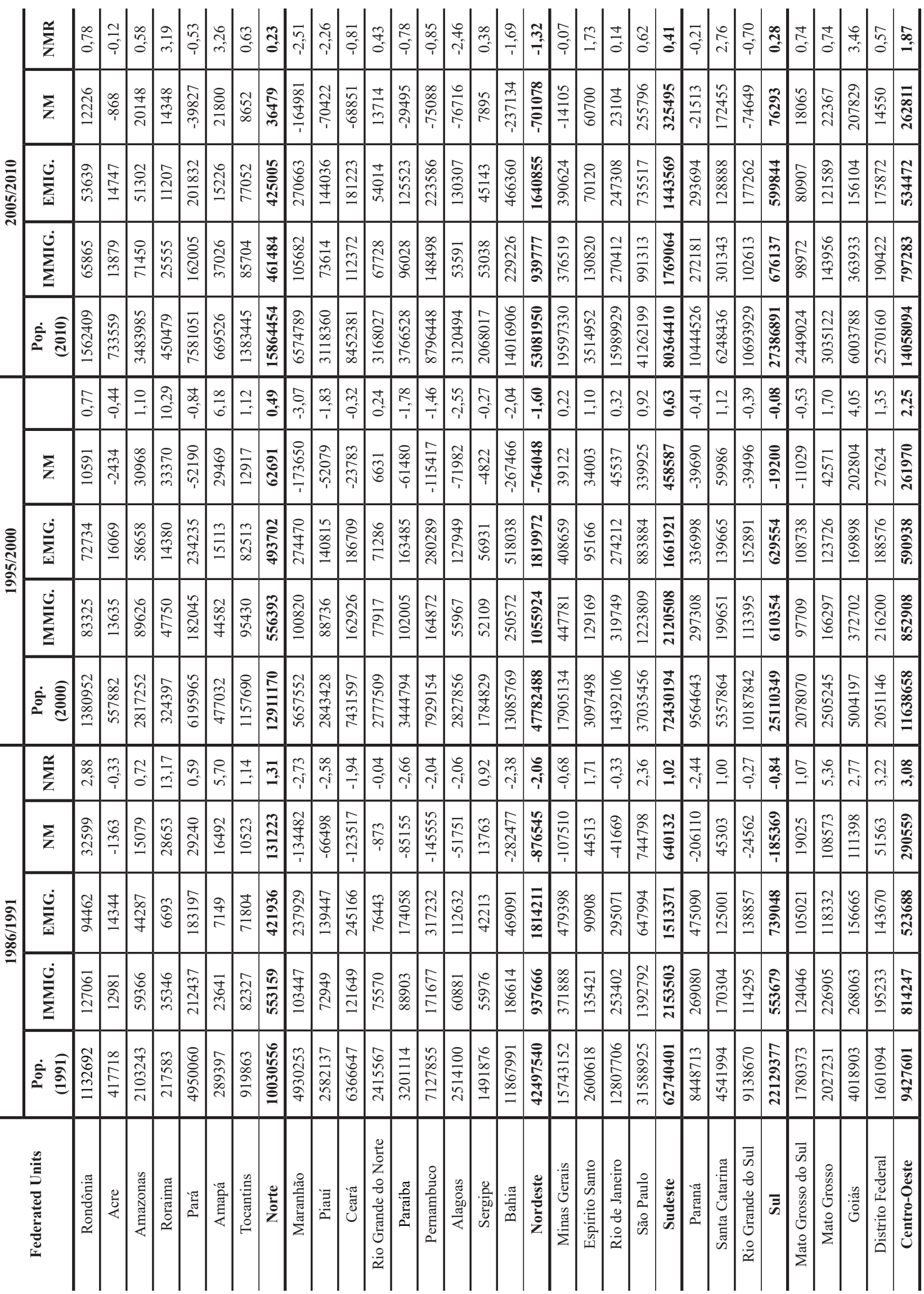

Table 1 - Brazil (Federated Units), total population, immigrants, emigrants, net migration and net rate of fixed date migration - 1986/1991, 1995/2000 and 2005/2010

Source: IBGE, Demographic Census 1991, 2000 and 2010. 

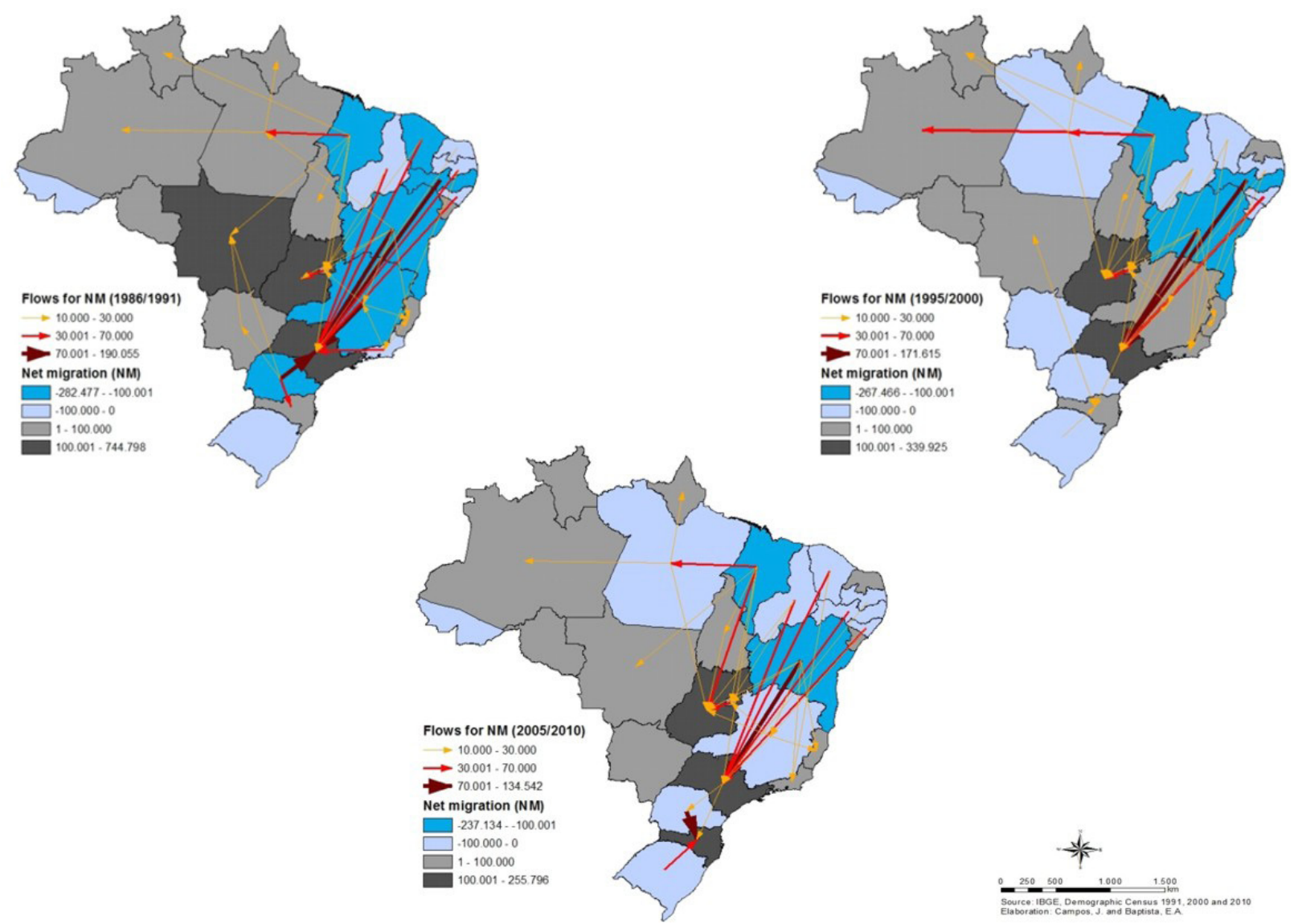

Figure 2 - Interstate flows for net migration: the five-year periods of 1986/1991 (a), 1995/2000 (b) and 2005/2010 (c)

Source: IBGE, Demographic Census 1991, 2000 and 2010.

Bahia and Pernambuco were mainly responsible for the emigration towards São Paulo (with flows of more than 70,000 people for each state and period) and Bahia and Pernambuco were the two northeastern states with the highest net loss of population in the period 1986/1991 (282,477 and 145,555 , respectively). In the period 1995/2000 there was a reduction in the negative migration balance in Bahia and Pernambuco but there were still significant losses and emigration to São Paulo, and Pernambuco's loss of second position in relation to the negative net migration to the State of Maranhão. In the period 2005/2010, it is interesting to note the continued reduction of the negative migration balance in Bahia and Pernambuco, the latter at a faster rate, which reflects the reduction of flows to São Paulo originating in Pernambuco. Bahia remained not only the main source of immigrants to São Paulo, but also the main state responsible for the negative migration balance of the Northeast, along with the state of Maranhão. However, São Paulo remains the main destination of northeastern emigrants in a continuing framework of population loss, except for Sergipe and Rio Grande do Norte, which had a positive net migration in the five-year period 2005-2010. It is also worth highlighting the state of Maranhão, which after a rise in population losses in the five-year periods 1986/1991 and 1995/2000, mainly to the North (Pará and Amazonas), and negative NMRs of $2.73 \%$ and $3.07 \%$, respectively, in the period 2005/2010 evidenced a slight reduction in the negative balance; the NMR remained representative (negative by $2.51 \%$ ). Similarly, in the latter period the states of Piaui and Alagoas also show negative and high NMRs in the order of $2.26 \%$ and $2.46 \%$, respectively. The State of Ceará deserves special attention because throughout the period in question it had the third largest population in the Northeast, with 8.4 million inhabitants in 2010 (a population similar to that of Pernambuco, with 8.8 million in the same period) while it was not 
ranked among the states that most lost population in the three five-year periods observed. Although negative net migration intensified between $1995 / 2000$ and 2005/2010 (-23.8 billion to -68.8 billion), the NMR was already below $1 \%$ in these two five-year periods $(-0.3 \%$ and $-0.8 \%$, respectively).

The general reduction of the negative migration balance in the Northeast is associated both with the reduction of emigration and the increase in immigration, in part associated with the return of native people. The economic development observed in Brazil during the 2000s, especially in the Northeast, with the expansion of some industrial centers (such as Recife, Fortaleza and Camaçari), coupled with the growth of income transfer programs such as the Bolsa Família, were to some extent instrumental in changing the configuration of migration in this region; both toward a greater power of retention of the resident population, as well as increasing return migration, an issue that will be examined in depth below.

It is important to note that it is not only factors associated with the place of origin, such as economic development in the Northeast (as set out above) that have been active in changing the migratory pattern. Factors at the destinations, such as violence (as in the case of large urban centers of the Southeast) and unemployment in major centers are a result of the accelerated process of urbanization observed in recent decades. This is marked by a large populational contingent with little schooling and in a worsening scenario, in view of the changes and new requirements of the labor market, which have acted as factors of "expulsion" of some migrants to their place of birth. In this sense, Brito and Oliveira (2016) state that:

Return migration has a strong association with aspects linked to the conditions of the labor market. Possibly, the saturation of the most central areas, which reduces the capacity to generate employment and new occupational opportunities is a factor that decisively affects the migrants' return strategies.

Thus, economic factors both at the origin and the destination have contributed to changes in the migratory pattern. As stated by Ojima and Fusco (2015) on the recent trends of the migrations:

This trend appears to indicate an improvement in the conditions that retain the population in the Northeast, but it may also indicate the difficulty of integrating migrants into the more dynamic centers, due both to the lower offer of employment and the higher selectivity, causing migrations with shorter duration, which are not satisfactorily captured by the census.

With regard to the Southeast region, there were positive net migration balances and rates in the period under analysis, although in absolute terms these gains are decreasing considerably. São Paulo and Espírito Santo had positive net migration in the three five-year periods. However, from 1986/1991 to 1995/2000 São Paulo reduced its surplus by around 55\%. By analyzing the columns of immigrants and emigrants in Table 1, it appears that this is mainly due to increased emigration, in part consisting of return migration. In the five-year period 1986/1991, São Paulo mainly received immigrants from the states of Bahia and Pernambuco (as has been verified above), in addition to Minas Gerais, Rio de Janeiro and Paraná. In the following five years, there was a strong reduction of immigrants from these last three states (Figure 2). However, Figure 3, which corresponds to fixed date return migration, shows strong emigration from São Paulo due to the sharp rise in return migration between the first two five-year periods analyzed, largely returning from São Paulo to Paraná, Minas Gerais and several northeastern states in the periods 1986/1991 and 1995/2000. In the period 2005/2010, the decrease of immigrants in São Paulo from Pernambuco was, to some extent, offset by the increase of immigrants originating in Piauí and Ceará (states that have had variations in net migration; negative in both cases in three five-year periods under review). Minas Gerais, which had reversed its migration balance from negative to positive in the first two five-year periods, largely due to lower population losses, mainly to São Paulo, evidenced a loss in population in the last reporting period, although this loss was only 14,105 people. Whereas Rio de Janeiro, which like Minas Gerais reversed its migration balance from negative to positive between the first two five-year periods, maintained a positive balance in the last five years, although it was lower than the previous period. 
In the South, the migratory balances were negative for the periods 1986/1991 and 1995/2000 and began to show positive net migration balances and rates in the period 2005-2010. Santa Catarina was the only state in the Southern region with positive balances for the whole period; in the last period there was a considerable increase. The maps in Figure 2 show that this increase in net migration of 45,303 and 59,986 in the periods $1986 / 1991$ and $1995 / 2000$, to 172,455 people in the period 2005-2010 (Table 1) is due to the significant increase in immigrants, in the order of 51\% between the last two five-year periods, originating largely from neighboring states (Paraná and Rio Grande do Sul). On the other hand, the states of Rio Grande do Sul and Paraná have traditionally lost population, although this trend has been decreasing in the case of Paraná, due to the reduction in net population losses to São Paulo and the increase of immigrants returning from that same state.

Finally, in the last 25 years all the states of the Center-west, with the exception of Mato Grosso do Sul in the second five-year period, showed positive net migration balances and rates. Goiás stood out among the states of this region as it had slightly higher net migration rates than the others in the last two five-year periods and an increase in the number of origins, in relation to the greater intensity of flows in the five-year periods 1995/2000 and 2005/2010, notably the increase in immigrants from Maranhão and the Federal District. In turn, Mato Grosso faces a substantial reduction in immigration, with a relative maintenance of the number of migrants in the periods in question. The Federal District showed positive migration balances, although they declined in the three five-year periods analyzed, largely due to an increased number of migrants, mainly between 1986/1991 and 1995/2000.

So it is worth asking if even the federated units with constant migratory gains will continue to have these levels in the future. Past experience has shown that over time, even spatial units with marked trends in net population gains tend to experience a reduction in their balances.

Table 2 shows the fixed date return immigrants for the five-year periods studied and their percentage contribution in view of the total of fixed date immigrants. In the North, for example, there was an increase in the number of return migrants, as well as an increase in their relative share in relation to the total migrants in five-year periods analyzed. It is noteworthy that over the periods analyzed, the states of Acre, Tocantins and Pará showed a higher proportion of returnees from the Northern region; in the five-year period $2005 / 2010$ this percentage was approximately $15 \%$. It is important to note that considerable return flows originating in a single FU have not been observed in this region (Figure 3), based on the cut of 10,000 people that was adopted (this number was set for all the periods, from the analysis of the distribution data).

In the states of the Northeast, the recovery over the past 25 years has been more expressive than in the northern states, in both absolute and percentage terms. Figure 3 shows a significant increase in return migration, especially to the states of Bahia, Pernambuco and Ceará, originating in São Paulo between the five-year periods 1986/1991 and 1995/2000. For example, in the period 1986/1991 the state of Bahia had 61,005 return immigrants, amounting to $32.69 \%$ of all the immigrants to the state. In the second five-year period, however, these numbers were 108,094 and 43.14\%, respectively. In other words, a considerable increase but followed by a reduction in the period 2005-2010 (Table 2). In the last five-year period, with the exception of the states of Sergipe and Rio Grande do Norte, the other northeastern states presented a proportion of returnees in relation to fixed date flows above $35 \%$. However, the most noteworthy is the state of Ceara during the three periods in question. In 1986/1991, 51.8\% (63,000) of immigrants to the state were returnees. In 1995/2000, the proportion dropped to $48.2 \%(78,500)$ but maintained the lead in the Northeast for the proportion of returnees to their state of birth, along with Paraíba, which in the same five-year period had $49.2 \%$ of returnees, among the fixed date immigrants. In 2005/2010, the State of Ceará remained the northeastern state with the highest proportion of returnees $(49,000$ or $43.6 \%)$.

As mentioned above, this significant proportion of returnee immigrants may be related both to the lack of opportunities in the destination and the development process (and increased power 
of attraction) of the Northeast. In the three five-year periods under review, it is possible to observe a higher proportion of returnees in the five-year period $1995 / 2000$, a period that coincided with a long phase of economic recession (observed since the 1980s) but also by the creation of the Real Plan and the stabilization of inflation. These factors may possibly be associated with the intensification of the migration process (since in this period there was an increase in migration as a whole) as well as the intensification of return migration.

Table 2 - Brazil (Federated Units), fixed date return migrants - 1986/1991, 1995/2000 and 2005/2010

\begin{tabular}{|c|c|c|c|c|c|c|}
\hline \multirow[b]{2}{*}{ Federated Units } & \multicolumn{2}{|c|}{ 1986/1991 } & \multicolumn{2}{|c|}{$1995 / 2000$} & \multicolumn{2}{|c|}{$2005 / 2010$} \\
\hline & $\begin{array}{c}\text { Return mi- } \\
\text { grants }\end{array}$ & Immig. total \% & $\begin{array}{c}\text { Return mi- } \\
\text { grants }\end{array}$ & $\begin{array}{c}\text { Immig. total } \\
\%\end{array}$ & $\begin{array}{c}\text { Return mi- } \\
\text { grants }\end{array}$ & Immig. total \% \\
\hline Rondônia & 2093 & 1,65 & 6091 & 7,31 & 6760 & 10,26 \\
\hline Acre & 2195 & 16,91 & 2784 & 20,42 & 2125 & 15,31 \\
\hline Amazonas & 3712 & 6,25 & 8620 & 9,62 & 7280 & 10,19 \\
\hline Roraima & 498 & 1,41 & 1007 & 2,11 & 1620 & 6,34 \\
\hline Pará & 17491 & 8,23 & 27797 & 15,27 & 26127 & 16,13 \\
\hline Amapá & 1555 & 6,58 & 2326 & 5,22 & 2530 & 6,83 \\
\hline Tocantins & 10764 & 13,07 & 14271 & 14,95 & 12970 & 15,13 \\
\hline Maranhão & 34997 & 33,83 & 43187 & 42,84 & 40915 & 38,72 \\
\hline Piauí & 28236 & 38,71 & 40998 & 46,20 & 28695 & 38,98 \\
\hline Ceará & 63058 & 51,84 & 78469 & 48,16 & 49004 & 43,61 \\
\hline Rio Grande do Norte & 27658 & 36,60 & 27749 & 35,61 & 20435 & 30,17 \\
\hline Paraíba & 43050 & 48,42 & 50154 & 49,17 & 39223 & 40,85 \\
\hline Pernambuco & 73555 & 42,84 & 73557 & 44,61 & 54050 & 36,40 \\
\hline Alagoas & 17006 & 27,93 & 23239 & 41,52 & 20274 & 37,83 \\
\hline Sergipe & 14296 & 25,54 & 13512 & 25,93 & 13502 & 25,46 \\
\hline Bahia & 61005 & 32,69 & 108094 & 43,14 & 86640 & 37,80 \\
\hline Minas Gerais & 155323 & 41,77 & 161044 & 35,96 & 111447 & 29,60 \\
\hline Espírito Santo & 24954 & 18,43 & 21832 & 16,90 & 18744 & 14,33 \\
\hline Rio de Janeiro & 37667 & 14,86 & 49351 & 15,43 & 47114 & 17,42 \\
\hline São Paulo & 130838 & 9,39 & 116430 & 9,51 & 156873 & 15,82 \\
\hline Paraná & 93544 & 34,76 & 94652 & 31,84 & 79042 & 29,04 \\
\hline Santa Catarina & 36462 & 21,41 & 34961 & 17,51 & 39013 & 12,95 \\
\hline Rio Grande do Sul & 49312 & 43,14 & 40434 & 35,66 & 39922 & 38,91 \\
\hline Mato Grosso do Sul & 15930 & 12,84 & 14998 & 15,35 & 16136 & 16,30 \\
\hline Mato Grosso & 8062 & 3,55 & 10364 & 6,23 & 11497 & 7,99 \\
\hline Goiás & 48400 & 18,06 & 54292 & 14,57 & 47785 & 13,13 \\
\hline Distrito Federal & 6376 & 3,27 & 9481 & 4,39 & 19939 & 10,47 \\
\hline Brazil & 1008037 & 20,11 & 1129694 & 21,74 & 999662 & 21,53 \\
\hline
\end{tabular}

Source: IBGE, Demographic Census 1991, 2000 and 2010.

If on the one hand, the causes of the widespread reduction of migration in the five-year pe$\operatorname{riod} 2005 / 2010$, compared to $1995 / 2000$ are not yet known - although they are possibly associated with reduced migration, understood as a change in fixed residence and increases in other types of mobility (such as pendularity, which does not necessarily imply a change of residence), facilitated by advances in transport systems in the context of globalization - for the purposes of this study, the important point to note is that regardless of this reduction in the volume of migration, the weight (or proportion) of return migration reduced between the two five-year periods for the Northeast Region. Although it remains the region with the largest weight of returnees (among immigrants), this reduction in the last five years may possibly be associated with accelerated economic growth in the country in the 2000s and to some extent, may have contributed to the permanence of people 

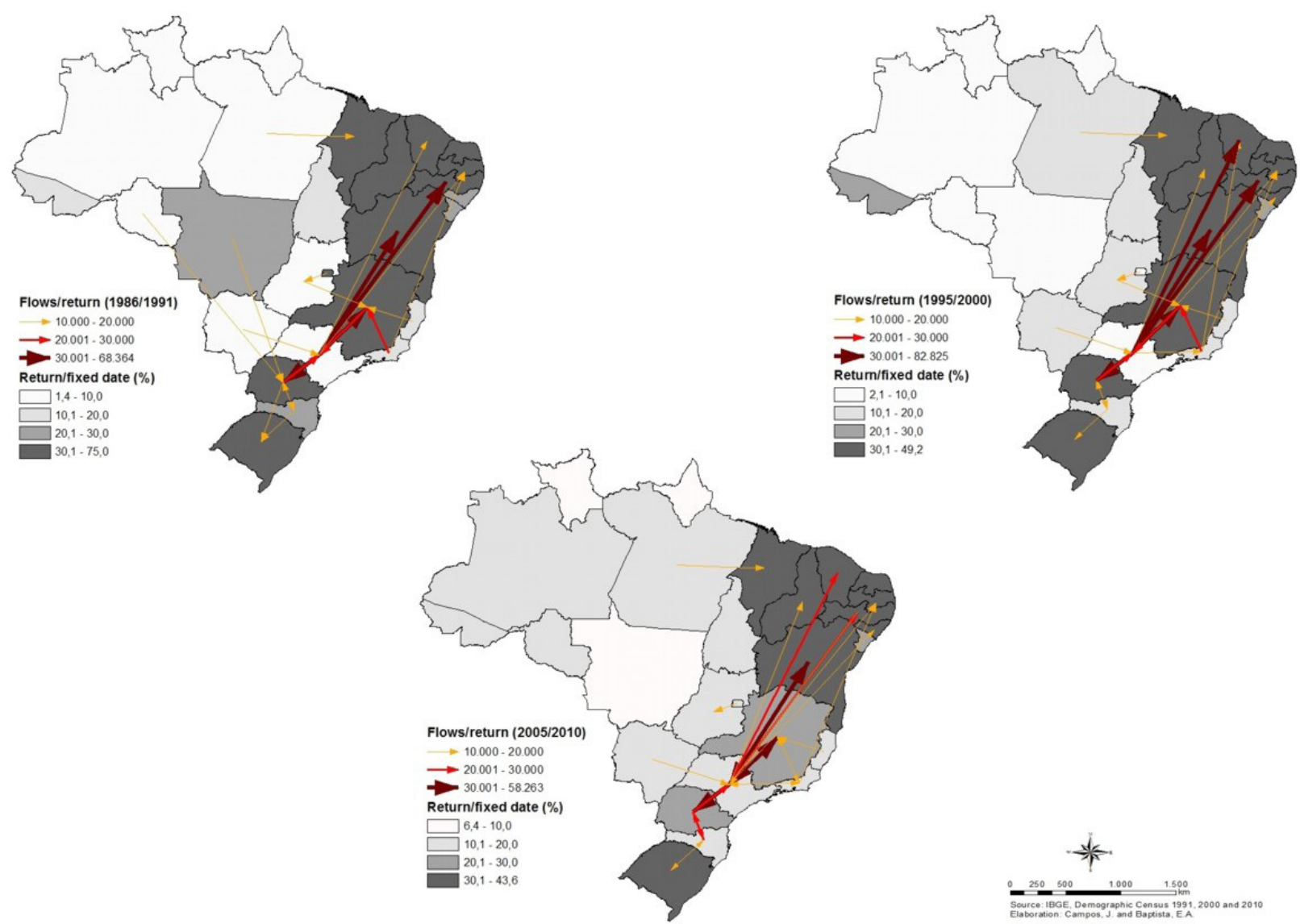

Figure 3 - Interstate flows relating to fixed date return migrants for the five-year periods of 1986/1991 (a), $1995 / 2000$ (b) and 2005/2010 (c)

Source: IBGE, Demographic Census 1991, 2000 and 2010.

from the Northeast at the destination. On the other hand, this phenomenon may simply be reflecting a trend of the population stock (based on the hypothesis that a significant portion of the population of the Northeast, emigrants in the past, have already returned to their place of birth). Thus, as stated by Ojima and Fusco (2015), the results should be interpreted with caution, as the increase or decrease in the volume of returnee migrants may be associated, for example, with a change in the migration profile of the family - such as the growing importance of immigrants who are the offspring of returnees - which, in turn, shows the need for studies that address the indirect effects of migration.

The effort of associating return migration trends with economic issues becomes important when it is observed that the behavior of the migratory component varies considerably depending on the region being studied. Unlike the Northeast, the states of the Southeast do not exhibit a standard behavior in relation to return migration. The main highlight is the state of Minas Gerais, whose reversal of negative net migration in previous decades has a strong correlation with the increase in return migration, mainly from the State of São Paulo. In turn, the other states of the region have a lower proportion of returnees in the five-year flows. While Espirito Santo has a reduction in the proportion of returnees, São Paulo and Rio de Janeiro are on the opposite path. In the case of São Paulo, return migration originates from the states of Paraná and Minas Gerais in the five-year period 1995/2000. In addition to these two states, Bahia contributed significantly in the period 2005/2010 to the increase of returnees in São Paulo.

In the Southern region, in the three five-year periods analyzed, the state of Paraná "benefited" from returnees from the state of São Paulo. There has been a continuous reduction of returnees throughout the period, although it is the state with the largest number of returnees. In turn, in Santa Catarina the absolute number of returnees remained relatively constant, although the proportion 
of these has fallen in relation to the fixed date flows. Finally, for the entire period the state of Rio Grande do Sul has the highest proportion of fixed date returnees, although there was a reduction in absolute terms.

Regarding the Center-west region, although it has grown in the last three decades the contribution of return migration was not significant compared to other Brazilian regions. This can be verified by the absence of return migration flows above 20,000 people, as shown in Figure 3.

As discussed in the methodology section, the new requirement to include fixed dates since the 1991 census allowed the calculation of short-term return migration, which corresponded to individuals who emigrated and returned within five years. This definition characterizes full return migration.

Although recent surveys point to a decrease in interstate flows, given the current Brazilian migratory pattern, Table 3 shows a significant increase in short-term movements, particularly between 1986/1991 and 1995/2000, both in absolute and relative terms. As mentioned above, in the current context of globalization increases in new types of mobility have been observed, both those that do not involve a change of residence (and are not the object of this study, as in the case of pendularity), and changing residence in short intervals of time, as in the case of short-term migration (which corresponds in turn to a type of direct estimate of return migration).

Table 3 - Brazil (FUs), short-term immigrants, percentage of short-term immigrants in relation to the total final stage immigrants, by Federated Units - 1986/1991, 1995/2000 and 2005/2010

\begin{tabular}{|c|c|c|c|c|c|c|}
\hline \multirow{3}{*}{ Federated Units } & \multicolumn{2}{|c|}{$1986 / 1991$} & \multicolumn{2}{|c|}{$1995 / 2000$} & \multicolumn{2}{|c|}{$2005 / 2010$} \\
\hline & \multicolumn{2}{|c|}{ short-term immigrants } & \multicolumn{2}{|c|}{ short-term immigrants } & \multicolumn{2}{|c|}{ short-term immigrants } \\
\hline & total & $\%$ immig. & total & $\%$ immig. & total & $\%$ immig. \\
\hline Rondônia & 4326 & 3,29 & 27633 & 24,90 & 22236 & 25,24 \\
\hline Acre & 926 & 6,66 & 3918 & 22,32 & 5531 & 28,50 \\
\hline Amazonas & 6595 & 10,00 & 12588 & 12,32 & 29324 & 29,10 \\
\hline Roraima & 1492 & 4,05 & 4820 & 9,17 & 7331 & 22,29 \\
\hline Pará & 9768 & 4,40 & 63142 & 25,75 & 68230 & 29,63 \\
\hline Amapá & 1064 & 4,31 & 6715 & 13,09 & 9524 & 20,46 \\
\hline Tocantins & 6756 & 7,58 & 25423 & 21,04 & 21964 & 20,40 \\
\hline Maranhão & 15667 & 13,15 & 39916 & 28,36 & 46553 & 30,58 \\
\hline Piauí & 16801 & 18,72 & 29500 & 24,95 & 26713 & 26,63 \\
\hline Ceará & 40479 & 24,97 & 60999 & 27,24 & 60854 & 35,13 \\
\hline Rio Grande do Norte & 10406 & 12,10 & 24227 & 23,72 & 24013 & 26,17 \\
\hline Paraíba & 22569 & 20,25 & 40146 & 28,24 & 33194 & 25,69 \\
\hline Pernambuco & 31998 & 15,71 & 60011 & 26,69 & 66527 & 30,94 \\
\hline Alagoas & 8451 & 12,19 & 22442 & 28,62 & 24768 & 31,61 \\
\hline Sergipe & 9362 & 14,33 & 16454 & 24,00 & 18652 & 26,02 \\
\hline Bahia & 48412 & 20,60 & 93087 & 27,09 & 113903 & 33,20 \\
\hline Minas Gerais & 60324 & 13,96 & 123896 & 21,67 & 166775 & 30,70 \\
\hline Espírito Santo & 8233 & 5,73 & 32871 & 20,29 & 42639 & 24,58 \\
\hline Rio de Janeiro & 43841 & 14,75 & 93687 & 22,66 & 128001 & 32,13 \\
\hline São Paulo & 91993 & 6,20 & 358539 & 22,66 & 421794 & 29,85 \\
\hline Paraná & 61391 & 18,58 & 91018 & 23,44 & 109797 & 28,74 \\
\hline Santa Catarina & 13653 & 7,42 & 47426 & 19,19 & 74789 & 19,88 \\
\hline Rio Grande do Sul & 13850 & 10,81 & 47395 & 29,48 & 72049 & 41,25 \\
\hline Mato Grosso do Sul & 8744 & 6,58 & 24639 & 20,14 & 33360 & 25,21 \\
\hline Mato Grosso & 11790 & 4,94 & 52607 & 24,03 & 51169 & 26,22 \\
\hline Goiás & 19586 & 6,81 & 65395 & 14,93 & 106633 & 22,66 \\
\hline Distrito Federal & 10264 & 4,99 & 18331 & 7,82 & 50041 & 20,81 \\
\hline Brazil & 578741 & 10,35 & 1486826 & 22,25 & 1836364 & 28,34 \\
\hline
\end{tabular}

Source: IBGE, Demographic Census 1991, 2000 and 2010. 
In the five-year period of 1986/1991, the volume of short-term interstate return immigrants totaled a little less than 580,000 people in Brazil, that is, $10.4 \%$ of the last stage migrants, with less than 5 years of residence. This contingent increased $156.9 \%$ (to nearly 1.5 million people) in the following period, representing $22.3 \%$ of the total. It is noteworthy that all the units of the federation, without exception, experienced substantial percentage increases in this type of mobility. The largest of these occurred in those states whose participation was lower in the first five-year period under consideration. Some noteworthy points are: the states of the Northern region, the most recently occupied area, as well as the State of São Paulo, which has the largest volume of all the units of the federation and a relative increase of $289.7 \%$ between the two periods; and finally, Mato Grosso, with the highest relative increase, if we disregard the states of the Northern region. In the northeastern region, the state of Ceará stands out with the highest proportion observed in the five-year period 2005/2010 (35.1\% of the final stage migrations were returnees). Therefore, there is strong evidence that the beginning of this new century was marked by the intensification of back and forth interstate migration in short periods of time.

The data of the 2010 Population Census shows that there was an increase of almost 350,000 short-term returnee immigrants when comparing the period 2005-2010 with the earlier, 1995-2000. Relatively more modest than the increase between the first two five-year periods, the data for the period 2005/2010, however, show that short-term returnees in Brazil as a proportion of the total of migrants for the five years $(28.3 \%)$ is greater than in the period 1995-2000.

In terms of relative increases, the Federal District (173.0\%) and Amazonas (133.0\%) stand out, while in absolute numbers, São Paulo is notable once more, with an increase of 63,000 people, followed by Minas Gerais (43,000 people), Goiás (41,000 people), Rio de Janeiro (34,000 people) and the Federal District (32,000 people). In contrast, there were also cases of decreases in the number of short-term returnees, such as Rondônia, Tocantins, Piaui, Paraiba and Mato Grosso. It is worth noting that throughout the country, only Tocantins and Paraiba had a relative decrease in short-term return migrants. In other words, the intensification of this mode of migration was very consistent, although its greatest rise took place in the last five years of the last century.

There seems to be an inverse relationship between the participation of short-term returnees and the history of migration balances, that is, where there were large net population losses in the past, this participation is higher and vice versa. While the three highest percentages of short-term migrants were in Rio Grande do Sul, Ceara and Bahia, the lowest three were in Santa Catarina, Tocantins and Amapá.

In short, the information analyzed makes the volume of the downward trend of interstate migratory balances clear, both positive and negative, a fact also accompanied by the regionalization of flows and the emergence of new forms of mobility, as highlighted by various authors (WEDGE and BAENINGER, 2005; BAENINGER, 2008; RIGOTTI 2006 and 2008; among others). Paradoxically, it seems that population mobility has intensified, becoming a trend at the beginning of this century.

\section{FINAL CONSIDERATIONS}

In the final decade of the last century, migration scholars in Brazil were faced with new forms of mobility, which are still far from being fully elucidated. In summary, at the beginning of the millennium the whole group of NMRs of the regions presented in this article shows that, proportionally, the Center-west was the one that most attracted people from other regions, followed by the North and Southeast. In the South, the highlight is state of Santa Catarina that attracts people from Parana and Rio Grande do Sul, given the virtually zero balance of the region as a whole. Continuing the historical inability to retain people within their regional boundaries, the Northeast continues with net losses, although evidence shows that some of its states are attracting migrants native to the 
region. Whether for economic or purely demographic issues (stock) it is unlikely that the volume of returnees to the region will continue at the same level in the coming decades.

From the point of view of population flows, the inability of destinations to retain migrants for long periods, such as the phase of rapid urbanization, a greater migratory turnover, changes in the metropolitan areas and the emergence of new areas to retain migrants, mark the turn of the millennium.

This article aimed to shed light on some of these aspects, using more recent information that points to a likely worsening of the spatial mobility of migrants, paradoxically accompanied by a decrease in interstate migration balances, especially those over a longer distance. Many of the issues raised and analyzed here need to be examined in depth, with new studies based on sample results of the 2010 Population Census. The apparent decline in population mobility between the federated units (which many attribute to the cooling of migration balances) has not been confirmed so far. On the contrary, the evidence suggests that it has increased, albeit with new contours. As stated by Ojima and Fusco (2015) "the changes observed in the national economy are not yet sufficient to eliminate regional inequalities or at least provide minimum conditions for the social reproduction of the population in their place of birth."

Given the above and the works we investigated, some of which are referenced in this text, we conclude that the complexity of migration studies poses a major challenge for scholars of the theme. For them to deal with this growing difficulty it is necessary to expand their conceptual categories, their benchmarks and also their measuring instruments and data sources.

More specifically, the great contemporary challenge on the international agenda of mobility studies is the need to associate migratory phenomena with development, as well as the causal factors underlying migration (DE HAAS, 2010). As stated by Ojima and Fusco (2015), economic transformations, such as de-concentration and productive restructuring, were considered important elements in the explanations of the changes observed in the 1980s and 1990s but their range was not satisfactory, which has required theoretical and methodological efforts to overcome the challenges to interpret the country's recent migratory dynamics. In this sense, some questions can be raised as an agenda for future studies, such as a possible relationship between return migration and improvements in local living conditions. For example, the increase in income transfer programs in the Northeast, especially in the poorest municipalities (municipalities that were, in their turn, the source of many migrants in the past) [SIQUEIRA et al., 2008].

Furthermore, economic development in the areas of origin, for example, the expansion of the petrochemical complex of Camaçari, the textile hub of Fortaleza, the mining-metallurgical complex of Carajás, the agro-industrial pole of Petrolina / Juazeiro, among others, together with unemployment, a lack of housing, violence and difficulty in accessing public services in the destination contribute to some extent to reduce emigration and increase return migration.

In addition to the economic issues, we must also consider new demographic information, such as the comparison between the return migrants, migrants who have not returned and the native population, ${ }^{9}$ and new arrangements such as the relationship between return migration and family structure (or household), as is the case of the indirect effects of migration, a hitherto unexplored theme on the agenda on recent migration trends in Brazil.

In this sense, identifying and analyzing of recent trends in return migration are the elements discussed in this article and are fundamental to develop the current agenda. However, the challenge is to set the future agenda to research the profile of returnees, the causal factors associated with this phenomenon, new demographic arrangements (such as an analysis of the indirect effects associated with the return), and new areas of intra-regional migration. These are key elements for regional planning and the development of public policies.

9 Queiroz and Baeninger (2014) compare return migrants, non-returned migrants and non-migrants in relation to selectivities in the labor market, for the state of Ceará, from the census of 1991, 2000 and 2010. 
Return migration is undoubtedly one of the principal0202017 phenomena occurring in Brazilian migration in recent decades. It seems clear, according to studies by Fazito (2005), that the returnees have unique and essential functions in the whole social process of migration. Be it the symbolic aspects and social legitimation of displacement or the operational aspects of the flows. In addition, returnees have the primary function of "closing" the migration system and confer a decisive sense to displacement, ensuring the circularity of population movements and the legitimacy of the events in the life cycles of individuals and groups.

\section{BIBLIOGRAPHIC REFERENCE}

BAENINGER, R. Novos Espaços da Migração no Brasil: Anos 80 e 90...In: XII ENCONTRO NACIONAL DE ESTUdOS POPULACIONAIS, 2000, Caxambu. Anais... Belo Horizonte: ABEP, 2000.

BAENINGER, R. Tendências do crescimento demográfico nos aglomerados urbanos. In: NETO, E. R.; BÓGUS, C. M. (eds.). Saúde nos aglomerados Urbanos. Brasília: Org. Pan-Amer. da Saúde, 2003, p.97-136.

BAENINGER, R. Rotatividade migratória: um novo olhar para as migrações no século XXI. Anais do XVI Encontro Nacional de Estudos Populacionais, Caxambu, 2008.

BRITO, F. Brasil final de século: a transição para um novo padrão migratório. In: FAUSTO. (Org.). Transições Migratórias. 7 ed. Fortaleza: Iplance, 2003, p. 15-54.

BRITO, D.J.M.; OLIVEIRA, A.M.H.C. Determinantes da migração e da migração de retorno no Nordeste. In: VII Cong. da Assoc. Latino-Americana de População (ALAP) e XX Enc. Nac. de Estudos Populacionais (ABEP). Anais... Foz do Iguaçú, 2016.

CARVALHO, J. A. M. de. \& RIGOTTI, J.I.R. Os dados censitários brasileiros sobre migrações internas. Revista Brasileira de Estudos Populacionais. São Paulo, v.15, n.2, 1998.

COSTA, C.C.R.C. A migração de retorno para o estado da Bahia. 2007, 162 p. Dissertação (Mestrado em Geografia) - Tratamento da Informação Espacial, PUC/MG, Belo Horizonte, 2007.

CUNHA, J. M. P.; BAENINGER, R. A migração nos estados brasileiros no período recente: principais tendências e mudanças. Bahia Análise \& Dados, Salvador - BA/SEI, v.10, n.4, p.79-106, mar. 2001.

CUNHA, J. M. P.; BAENINGER, R. Cenários da migração no Brasil nos anos 90. Caderno do CRH, Salvador, v. 18 n. 43, 2005.

CUNHA, J. P. M. São Paulo apresenta migração negativa. Comciência, São Paulo, número 07, fev. 2006. Disponível em: <http://www.comciencia.br/noticias/2006/02/migracao.htm>. Acesso em: 23 jul. 2006.

DE HAAS, H. Migration transitions: a theoretical and empirical inquiry into the developmental drivers of international migration. Working Papers Series, 24, 2010.

FAZITO, D. Dois aspectos fundamentais do "retorno": símbolos e topologias dos processos de migração e sua circularidade. Belo Horizonte: CEDEPLAR/UFMG, 2005, 16p.

GARCIA, R. A.; RIBEIRO, A. de M. Movimentos migratórios em Minas Gerais. In: XI SEMINÁRIO SOBRE A ECONOMIA MINEIRA, 2004, Diamantina, Anais... Belo Horizonte, 2004, p. 15.

JUSTO, W. R.; SILVEIRA NETO R. da M. Migração inter-regional no Brasil. Economia, Brasília (DF), v.7, n.1, p.163-187, jan./jul. 2006.

MARTINE, G. A redistribuição espacial da população brasileira durante a década de 80 . Texto para discussão no 329. Rio de Janeiro: IPEA, jan. 1994, 47 p.

MARTINS, J. de S. Não há terra para plantar neste verão. Petrópolis: Vozes, 1986.

OJIMA, R.; FUSCO, W. Migrações e nordestinos pelo Brasil. p.11-26. In: OJIMA, R. FUSCO, W. Migrações Nordestinas no Século 21 - Um Panorama Recente. São Paulo: Editora Edgard Blücher, 2015.

QUEIROZ, S. N.; BAENINGER, R. Migração Interestadual de Retorno e Seletividade no Mercado de Trabalho Cearense. In: VI da Associação Latinoamericana de População. Lima, Perú, 2014. 
RIBEIRO, J. T. L. Estimativa da migração de retorno e de alguns de seus efeitos demográficos indiretos no nordeste brasileiro, 1970/1980 e 1981/1991. 1997, 206 p. Tese (Doutorado em Demografia) - Centro de Desenvolvimento e Planejamento Regional, Universidade Federal de Minas Gerais, Belo Horizonte.

RIGOTTI, J. I. R. Técnicas de Mensuração das migrações, a partir de dados censitários. 1999. Tese (Doutorado CEDEPLAR). Universidade Federal de Minas Gerais, Belo Horizonte, 1999.

RIGOTTI, J. I. R. A geografia dos fluxos populacionais brasileiros. Estudos Avançados, São Paulo, v.20, n.57, p.237-254, mai./ago. 2006.

RIGOTTI, J. I. R. A (re)distribuição da população brasileira e possíveis impactos sobre a metropolização. In: 32 ${ }^{\circ}$ Encontro da ANPOCS. Caxambu. Disponível em: http://200.152.208.135/anpocs/trab/adm/impressao_gt.php?id_grupo=55\&publico=S, 2008.

SANTOS JUNIOR, E.R. et al. Seleção e Diferenças Regionais de Renda no Brasil. Pesquisa e Planejamento Econômico, Rio de Janeiro, v. 35, n.3, p. 299-331, dez. 2005.

SAYAD, A. O retorno: elemento constitutivo da condição do migrante. Travessia, São Paulo, Revista do Centro de Estudos da Migração, São Paulo, número especial, 21 p., jan. 2000.

SIQUEIRA, L.B.O; MAGALHÃES, A.M.; SILVEIRA NETO, R.M. Uma análise de migração de Retorno no Brasil: Perfil do migrante de Retorno, a Partir do Censo de 2000. In: XI Encontro Regional de Economia, 2006, Fortaleza. Anais... 2006. 